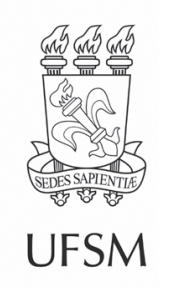

\title{
Artigos
}

\section{O papel das zonas de amortecimento na efetividade da proteção ambiental da Floresta Nacional de Palmares, Piauí, Brasil}

\author{
The role of buffer zones in the effectiveness of the environmental \\ protection in Floresta Nacional de Palmares, Piauí state, Brasil
}

\author{
Maria Letícia Stefany Monteiro Brandão ${ }^{\oplus}$ \\ Francisco das Chagas Paiva Silva ${ }^{\oplus}$ \\ Ana Carolina Chaves Fortes ${ }^{\oplus}$ \\ Gaspar da Silva Alencar" $\odot$ \\ Israel Lobato Rocha"I' $\odot$ \\ Bruna de Freitas Iwata' ${ }^{\oplus}$
}

'Instituto Federal do Piauí, Teresina, PI, Brasil

"Instituto Chico Mendes de Conservação da Biodiversidade, Altos, Pl, Brasil

'IIInstituto Federal do Piauí, Corrente, PI, Brasil

\section{RESUMO}

A pesquisa teve como objetivo avaliar a efetividade das zonas de amortecimento (ZA) enquanto instrumentos legais de proteção, no entorno das áreas protegidas da Floresta Nacional (Flona) de Palmares no papel da proteção ambiental. A pesquisa foi desenvolvida na Flona de Palmares, localizada no município de Altos - estado do Piauí. Foram realizados levantamentos bibliográficos, e utilizou-se, principalmente, a Legislação Ambiental e material de divulgação técnica e científica. Elaborou-se um mapa utilizando software de geoprocessamento Qgis para delimitar a ZA da Flona, e o mapeamento da expansão urbana foi feito por meio de observação de imagens de satélite. Embora a Flona esteja a uma distância considerável de adensamentos urbanos, ela é pressionada pelas propriedades e comunidades rurais que vem crescendo ao longo dos anos em seu entorno, o que representa uma ameaça direta à Unidade de Conservação (UC). O avanço dessas áreas em direção à UC configura fator de risco a ser considerado. Existem conflitos com os empreendimentos limítrofes à UC, e, ademais, carência de um plano de manejo eficiente e de sua aplicação, esses são alguns dos problemas identificados e que dificultam a efetividade da ZA da Flona de Palmares.

Palavras-chave: Legislação ambiental; Áreas protegidas; Bioma caatinga; Uso e ocupação do solo 


\section{ABSTRACT}

The research aimed to evaluate the effectiveness of the buffer zones(BZ) as legal instruments of protection, around the protected areas of the National Forest (Flona) of Palmares in the role of environmental protection. The research was carried out at Flona de Palmares, located in the municipality of Altos - PI state. Bibliographic surveys were carried out and, mainly the Environmental Legislation and technical and scientific dissemination material were used. A map was created using Qgis geoprocessing software to delimit the zone of Flona and the mapping of urban expansion was done through observation of satellite images. Although Flona is a considerable distance from urban densities, it is under pressure from rural properties and communities that have been growing over the years in its surroundings, which represents a direct threat to the Conservation Unit (CU). The progress of these areas towards CU is a risk factor to be considered. There are conflicts with enterprises bordering CU and, in addition, the lack of an efficient management plan and its application, these are some of the problems identified and that hinder the effectiveness of the BZ at Flona de Palmares.

Keywords: Environmental legislation; Protected areas; Caatinga biome; Land use and occupation

\section{INTRODUÇÃO}

A ideia de conservação da natureza tem requerido pensar a manutenção de áreas naturais com pouca ou nenhuma alteração antrópica. Uma das alternativas para a conservação foi a criação de Unidades de Conservação (UC), ou áreas territoriais legalmente protegidas, com o intuito de resguardar a biodiversidade e os recursos naturais (GALVÃO, 2018).

Atreladas a esses espaços, as zonas de amortecimento são delimitações periféricas que ultrapassam os limites políticos das UC, buscando a estabilidade ecológica e protegendo a unidade dos efeitos externos que possam influenciar de forma negativa a sua conservação. Visam também estabelecer de forma planejada a ligação entre a área protegida e a população que, de alguma forma, faz uso dos recursos naturais ali existentes (BRASILEIRO, 2018; MARQUES; COSTA; MOURA, 2019).

Previstas na Lei do Sistema Nacional de Unidades de Conservação art. $2^{\circ}$, XVIII, as Zonas de Amortecimento (ZA) aplicadas ao entorno das unidades de conservação tem como objetivo minimizar os impactos negativos sobre a unidade (BRASIL, 2000). E que, independentemente da existência de planos de manejo, deve ser estabelecida para as unidades de conservação com a intenção de reduzir esses impactos. 
Assim, em alguns países as zonas de amortecimento são definidas conceitualmente por leis ou outros instrumentos legais. A regulamentação jurídica de elementos da gestão de unidades de conservação como a ZA é importante para garantir sua aplicação e assegurar o cumprimento de seus objetivos (MOREIRA, 2015).

No entanto, estabelecer normas de uso, ocupação e monitoramento das ZA para evitar o avanço da ocupação inadequada sobre os limites da unidade, se torna tão importante quanto a própria gestão das UC. Vale ressaltar que mesmo a ZA não integrando a unidade, pela legislação, ela fica sujeita a um zoneamento que pode regular seu uso, permitindo ou restringindo a instalação de certas atividades econômicas ou até mesmo parcelamentos do solo (CASTRO, 2018). Logo, do ponto de vista legal, as ZAs tem definição, função e gestão claramente definidas.

Estudos que visam analisar o processo de antropização no entorno de UC, com a detecção de loteamentos e construções, bem como a utilização de métodos rápidos e automatizados que proporcionem a detecção de feições antrópicas são de fundamental importância para a fiscalização e o controle de ocupações irregulares na área abrangida pela ZA, constituindo então ferramentas de apoio para a gestão do território (FERREIRA et al., 2019).

Nesse sentido, esta pesquisa pretende contribuir com a discussão sobre o desempenho das zonas de amortecimento em unidades de conservação, e teve como objetivo avaliar a efetividade da Zona de Amortecimento da Floresta Nacional de Palmares no papel da proteção ambiental.

\section{MATERIAL E MÉTODOS}

\subsection{Caracterização da área de estudo}

A pesquisa foi desenvolvida na Floresta Nacional de Palmares (Flona de Palmares) que está localizada na Zona Rural do município de Altos, Piauí. (Figura 1). O município de Altos encontra-se situado na microrregião de Teresina, capital do Piauí. A Flona compreende uma área total de 170 ha. 
Figura 1 - Mapa de localização da Floresta Nacional de Palmares

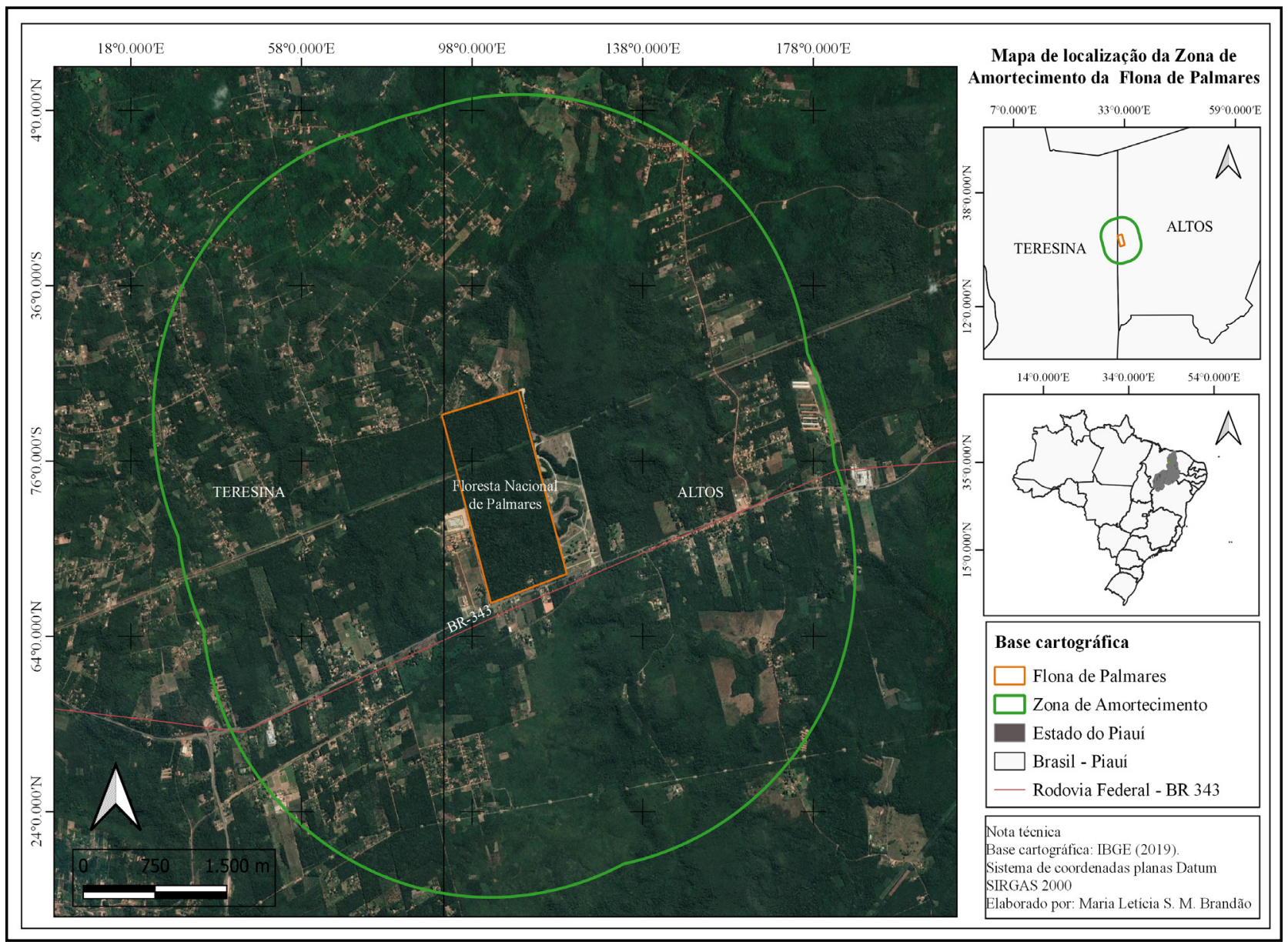

Fonte: Autores (2020)

Sua zona de amortecimento abrange os municípios de Teresina e Altos. E possui o marco M-01 como ponto extremo oeste do imóvel, nas coordenadas geográficas 0503'30,56524" S e 42³5' 47,92548" W, limitando-se com a colônia agrícola Major César de Oliveira. O ponto M-02 possui as coordenadas $05^{\circ} 02^{\prime 2} 28,49725^{\prime \prime} \mathrm{S}$ e 42³6'04,61087" W. Este último ponto confronta-se com as terras particulares do Z.L. O ponto M-03 possui como coordenadas $05^{\circ}$ 02' 20,34767" S e 42³5' 37,26544" W, este ponto confronta-se com terras particulares do S.B.P. O M-04, com coordenadas 050'20,90935" S e 42³5'21,91257" W, confronta-se com a BR 343 (LOPES, 2007).

A Floresta Nacional de Palmares está a cerca de 20 km de distância da zona urbana de Teresina. É a primeira e única unidade de conservação de uso sustentável 
na categoria de Floresta Nacional do Piauí, instituída pelo decreto de 21 de fevereiro de 2005, com o objetivo de promover o manejo do uso múltiplo dos recursos florestais, a manutenção de banco de germoplasma de espécies nativas e das características da vegetação do Cerrado e da Caatinga, bem como a proteção da biodiversidade, a recuperação de áreas degradadas e a educação ambiental.

A Flona de Palmares está inserida em uma zona de transição entre os biomas Caatinga e Cerrado, dois biomas importantes no cenário da biodiversidade brasileira. A unidade também abriga uma espécie rara e ameaçada de extinção, a Procnias Averano conhecida como Araponga do Nordeste, além de outras aves, e primatas como os Alouatta Ululata conhecido como guaribas. A importância ecológica da área, e a necessidade de proteger a cobertura vegetal, as espécies botânicas e a fauna existente, motivou a criação desta Unidade de Conservação de uso sustentável.

Esta UC é circundada por propriedades rurais de dimensões variadas, a maioria da população sendo residente nas propriedades rurais e assentamentos é composta por populações tradicionais que possuem o nível fundamental e médio de ensino, com faixa etária de 14 a 50 anos. No que diz respeito à infraestrutura, não possuem rede de abastecimento público de água: as comunidades são abastecidas por poços tubulares, sendo realizada a análise da qualidade da água anualmente, pela prefeitura, por exigência da Secretaria Estadual de Meio Ambiente e Recursos Hídricos (SEMAR). A região também não faz parte do roteiro da coleta pública de resíduos urbanos. Parte dos resíduos gerados é enterrada ou queimada e alguns moradores levam os resíduos gerados até o município de Teresina (SOUSA; SOARES; CERQUEIRA NETO, 2018).

\subsection{Procedimentos metodológicos}

Para alcance do objetivo proposto, a primeira etapa consistiu em revisão bibliográfica, utilizou-se, principalmente, a Legislação Ambiental (SNUC) e material de divulgação técnica e científica com abordagem legal sobre a efetivação da proteção ambiental pelo instrumento de delimitação e cumprimento da ZA. Com as informações 
coletadas via pesquisa documental foi elaborado um quadro demonstrativo com os dispositivos legais que tratam de áreas protegidas no Brasil.

Para avaliação do comportamento da FLONA em relação à ZA, foram elaborados mapas da área, com vistas a identificar o grau de intervenção antrópica na zona de contato do entorno e do território da FLONA. A elaboração dos mapas foi feita pelo software de geoprocessamento Qgis, com adoção de um buffer, denominado de zona de amortecimento, com raio de $3 \mathrm{~km}$ do limite da unidade, limite este estabelecido e fundamentado na Resolução do CONAMA n 428/2010 (CONSELHO NACIONAL DO MEIO AMBIENTE, 2010). O mapeamento da expansão urbana ocorreu pela observação de imagens de satélite (Google Earth) utilizada também para a vetorização e edição de polígono.

Assim, para a realização desta pesquisa foram utilizadas imagens do Landsat 8, sensor OLI. O Índice de Vegetação analisado foi utilizado das bandas 4 (vermelho) e 5 (infravermelho-próximo) para realização da equação. Foram tomadas e utilizadas as imagens dos dias 17 de agosto de 2019 e 02 de setembro de 2019. Com os dados de reflectância, foi possível obter o NDVI de acordo com a Equação (1) de Rouse et al. (1973):

$$
N D V I=\frac{\rho N I R-\rho R E D}{\rho N I R+\rho R E D}
$$

Em que: NDVI é o índice de vegetação com diferença normalizada; $\rho$ NIR é referente à banda do infravermelho próximo; $\rho$ Red é a banda do vermelho no sensor Landsat 8. Os valores do NDVI variam de -1 a 1, quanto mais próximo de 1 maior a densidade da cobertura vegetal (POLONIO, 2015; LEITE; SANTOS; SANTOS, 2017).

\section{RESULTADOS E DISCUSSÃO}

\subsection{Principais instrumentos jurídicos de proteção ao entorno de áreas protegidas}

As zonas de amortecimento em alguns países são definidas por leis ou por outros instrumentos infralegais. A regulamentação jurídica de elementos da gestão 
de unidades de conservação como a Zona de Amortecimento (ZA) é importante para garantir sua aplicação e assegurar o cumprimento de seus objetivos (MOREIRA, 2015).

No Brasil, desde a década de 60, já havia uma preocupação em proteger áreas no entorno de terrenos estratégicos. O Quadro 1 aponta os principais instrumentos de proteção ao entorno de áreas protegidas.

Quadro 1 - Principais instrumentos de proteção ao entorno de áreas protegidas

\begin{tabular}{|c|c|c|}
\hline Ano & Instrumento legal & Descrição \\
\hline 1967 & $\begin{array}{l}\text { Lei n 5197/67. Dispõe sobre a } \\
\text { proteção à fauna e dá outras } \\
\text { providências. }\end{array}$ & $\begin{array}{c}\text { Art. 10. F) Estabelece que nos } \\
\text { estabelecimentos oficiais e açudes do } \\
\text { domínio público, bem como nos terrenos } \\
\text { adjacentes, até a distância de } 5 \mathrm{~km} \text {. Onde } \\
\text { são proibidas a utilização, a perseguição, } \\
\text { a destruição e a caça de espécimes da } \\
\text { fauna silvestre. }\end{array}$ \\
\hline 1979 & $\begin{array}{c}\text { Decreto } 84017 / 79 . \text { Aprova o } \\
\text { Regulamento dos Parques Nacionais } \\
\text { Brasileiros. }\end{array}$ & $\begin{array}{l}\text { O conceito de zona de amortecimento } \\
\text { ainda não aparece no Regulamento } \\
\text { dos Parques Nacionais Brasileiros, o } \\
\text { qual apresenta o termo zona de uso } \\
\text { especial, em que instalações necessárias } \\
\text { à administração, manutenção e serviços } \\
\text { do parque sejam implantadas na sua } \\
\text { periferia, de forma a não conflitarem com } \\
\text { seu caráter natural. }\end{array}$ \\
\hline 1990 & $\begin{array}{c}\text { Decreto 99.274/90. Regulamenta a Lei } \\
n^{\circ} 6.902 \text {, de } 27 \text { de abril de 1981, e a Lei } \\
\text { n 6.938, de } 31 \text { de agosto de 1981, } \\
\text { que dispõem, respectivamente sobre } \\
\text { a criação de Estações Ecológicas e } \\
\text { Áreas de Proteção Ambiental e sobre a } \\
\text { Política Nacional do Meio Ambiente, e } \\
\text { dá outras providências. }\end{array}$ & $\begin{array}{l}\text { Art. 27. Nas áreas circundantes das } \\
\text { Unidades de Conservação, num raio de } 10 \\
\text { km, qualquer atividade que possa afetar } \\
\text { a biota ficará subordinada às normas } \\
\text { editadas pelo Conama. }\end{array}$ \\
\hline 1990 & $\begin{array}{c}\text { Resolução Conama 013/1990. Dispõe } \\
\text { sobre normas referentes às atividades } \\
\text { desenvolvidas no entorno das } \\
\text { Unidades de Conservação }\end{array}$ & $\begin{array}{l}\text { Revogada pela Resolução n }{ }^{\circ} 428 \text {, de } 2010 . \\
\text { art. } 2 \text {. Toda atividade que pudesse } \\
\text { afetar a biota, prejudicando as } \\
\text { áreas circundantes das unidades } \\
\text { de conservação, em um raio de dez } \\
\text { quilômetros fosse licenciada pelo órgão } \\
\text { ambiental competente }\end{array}$ \\
\hline
\end{tabular}


Quadro 1 - Conclusão

\begin{tabular}{|c|c|c|}
\hline Ano & Instrumento legal & Descrição \\
\hline 1993 & Resolução Conama n 10/1993. & $\begin{array}{l}\text { IV - Entorno de Unidades de Conservação } \\
\text { - área de cobertura vegetal contígua aos } \\
\text { limites de Unidade de Conservação, que } \\
\text { for proposta em seu respectivo Plano } \\
\text { de Manejo, Zoneamento Ecológico/ } \\
\text { Econômico ou Plano Diretor de acordo } \\
\text { com as categorias de manejo. Inexistindo } \\
\text { estes instrumentos legais ou deles } \\
\text { não constando a área de entorno, o } \\
\text { licenciamento se dará sem prejuízo da } \\
\text { aplicação do disposto no artigo } 2^{\circ} \text { da } \\
\text { Resolução/CONAMA/nº } 013 / 90 \text {. }\end{array}$ \\
\hline 1998 & $\begin{array}{c}\text { Lei } n^{\circ} \text { 9.605/98. Dispõe sobre as } \\
\text { sanções penais e administrativas } \\
\text { derivadas de condutas e atividades } \\
\text { lesivas ao meio ambiente, e dá outras } \\
\text { providências. }\end{array}$ & $\begin{array}{l}\text { Art. 40. Causar dano direto ou indireto } \\
\text { às Unidades de Conservação e às } \\
\text { áreas de que trata o art. } 27 \text { do Decreto } \\
\text { n } 99.274 \text {, de } 6 \text { de junho de } 1990, \\
\text { independentemente de sua localização: } \\
\text { Pena - reclusão, de um a cinco anos. }\end{array}$ \\
\hline 2000 & $\begin{array}{c}\text { Lei 9.985/2000. Regulamenta o } \\
\text { art. 225, § 1ㅇ, incisos I, II, III e VII da } \\
\text { Constituição Federal, institui o Sistema } \\
\text { Nacional de Unidades de Conservação } \\
\text { da Natureza (SNUC) e dá outras } \\
\text { providências. }\end{array}$ & $\begin{array}{l}\text { Traz o conceito de zona de } \\
\text { amortecimento e ressalta que a zona } \\
\text { de amortecimento não faz parte da } \\
\text { unidade, mas fica sujeita, por força de Lei, } \\
\text { a um modo de zoneamento obrigatório, } \\
\text { que regula e permite certas atividades } \\
\text { econômicas. }\end{array}$ \\
\hline 2010 & $\begin{array}{l}\text { Resolução Conama 13/90. Revoga as } \\
\text { Resoluções n 10/1988, n 11/1987, } \\
\text { n 12/1988, n 13/1990. Dispõe, no } \\
\text { âmbito do licenciamento ambiental, } \\
\text { sobre a autorização do órgão } \\
\text { responsável pela administração da } \\
\text { Unidade de Conservação (UC). }\end{array}$ & $\begin{array}{l}\text { Art. } 1^{\circ} \text { - O órgão responsável por cada } \\
\text { Unidade de Conservação, juntamente } \\
\text { com os órgãos licenciadores e de meio } \\
\text { ambiente, definirá as atividades que } \\
\text { possam afetar a biota da Unidade de } \\
\text { Conservação. } \\
\text { Art. } 2^{\circ} \text { - o entorno das Unidades de } \\
\text { Conservação, num raio de } 10 \mathrm{~km} \text {, } \\
\text { qualquer atividade que possa afetar } \\
\text { a biota deverá ser obrigatoriamente } \\
\text { licenciada pelo órgão ambiental } \\
\text { competente. }\end{array}$ \\
\hline
\end{tabular}

Fonte: Autores (2020) 
Apesar de diferentes nomenclaturas, todos esses dispositivos reconheciam a zona de amortecimento (ZA), mas foi o SNUC, através da Resolução CONAMA n 13 de 1990, que usou pela primeira vez o termo "zonas de amortecimento", e que definiu que esse entorno deveria ter um raio de até $10 \mathrm{~km}$ ajustáveis pelo Plano de Manejo (MARQUES; COSTA; MOURA, 2019).

A Lei do SNUC foi criada após inúmeros conflitos. A Lei estabelece critérios e normas para a criação, implantação e gestão das Unidades de Conservação, além de ofertar embasamento para a sua gestão. Uma conquista em termos normativos foi a exigência de se estabelecer uma ZA para toda UC, a área do entorno da unidade também fica sujeita a restrições, de modo a minimizar danos decorrentes do aumento das pressões sobre os espaços protegidos (PROST; SANTOS, 2016; DINIZ et al., 2018).

É dever do órgão responsável pela administração da unidade de conservação estabelecer normas que regulamentem a ocupação e o uso dos recursos da zona de amortecimento, tal como definir os limites da zona de amortecimento e as respectivas normas, que poderão ser definidas no ato de criação da unidade ou posteriormente $(\mathrm{KOCH}, 2016)$.

Segundo resolução do Conama $n^{\circ}$ 428, de 17 de dezembro de 2010, a zona de amortecimento de UC sem plano de manejo deve ter um raio de no mínimo 3 km, nos casos de empreendimentos de significativo impacto ambiental, assim considerado pelo órgão ambiental licenciador, com fundamento em estudo de impacto ambiental e respectivo relatório de impacto ambiental (EIA/RIMA). Nos casos de licenciamento ambiental de empreendimentos não sujeitos a EIA/RIMA, a zona de amortecimento a ser considerada, para as UC que ainda não têm plano de manejo, é de no mínimo 2 km (CONSELHO NACIONAL DO MEIO AMBIENTE, 2010).

Mesmo protegidas por Lei, essas áreas tornam-se vulneráveis às ações antrópicas devido à falta de fiscalização ao uso inadequado do solo (REIS; COSTA, 2017), as alterações na paisagem natural podem gerar impactos, muitos irreversíveis. Portanto, é urgente a necessidade de estabelecer prioridades para conservação e 
proteção de sistemas de relevante interesse ecológico, promover compatibilização com usos e estabelecer contínua adaptação frente aos fatores que possam advir da expansão urbana em ZA (PIGNATON; SILVA; SILVA, 2017).

\subsection{Indicador de qualidade da Zona de Amortecimento}

Em toda zona de amortecimento da Flona de Palmares há fragmentação com resquícios de florestas, no entanto não há corredores ecológicos. Segundo Andrade et al. (2020), uma das principais consequências do crescimento de áreas rurais em áreas de vegetação é o processo de fragmentação florestal, o qual é caracterizado pela ruptura da unidade da paisagem, formando pequenos fragmentos florestais isolados onde anteriormente existia área de floresta contínua.

Essas fragmentações, além de reduzir os efeitos das atividades humanas sobre unidade, devem permitir o fluxo biológico entre os fragmentos, permitindo a manutenção de populações viáveis das espécies presentes na região, por meio de uma rede de fragmentos, atuando como complemento às UC (TAMBOSI, 2008).

A distribuição das manchas de florestas, seus tamanhos, formas e graus de isolamento determinam a riqueza de espécies que as mesmas possam manter. A forma tem influência direta na intensidade do efeito de borda que o fragmento está sujeito, quanto mais próximo da forma de um círculo, menor é a borda do fragmento, estando assim menos sujeito às perturbações externas. Além do isolamento dos fragmentos, determinando o quanto possam estar conectados, também a permeabilidade da matriz (dependendo dos elementos que a constitui, na forma de diferentes usos do solo) determina a intensidade do fluxo gênico das espécies florestais (WINAGRASKI et al., 2017; ANDRADE et al., 2020).

A partir da análise dos mapas de uso e cobertura do solo foi possível comparar a ocupação na zona de amortecimento da Flona num raio de $3 \mathrm{~km}$. As alterações nas classes de uso e cobertura do solo da ZA mostram a dinâmica, principalmente das atividades antrópicas. 
Os indicadores se constituem em instrumentos de avaliação, que devem ser adequados às realidades ambientais e socioeconômicas de cada região. A formulação de indicadores ambientais é indispensável na realização do diagnóstico ambiental e monitoramento nas Unidades de Conservação, pois fornece a situação real da área, e sem um diagnóstico eficiente implica nas outras etapas, como, por exemplo, na elaboração de um plano de manejo (SOUZA, 2011).

\subsection{Zona de Amortecimento da Flona de Palmares}

A Flona de Palmares não possui um plano de manejo, o que traz implicações na sua conservação direta e indireta, além de tornar sua zona de amortecimento mais suscetível às atividades antrópicas. Provavelmente, dentre muitos fatores e em função da ausência deste instrumento de gestão, observa-se um grande avanço no entorno da Flona, colocando em risco as suas características como Floresta. A Figura 1 aponta a delimitação e abrangência da ZA da Flona. O reconhecimento de limites visuais para a definição de Zonas de Amortecimento facilita o manejo e a gestão dessas áreas, pode ajudar na identificação e localização para a fiscalização, como também na divulgação destes limites para a sociedade.

A zona de amortecimento da Flona foi definida no Plano de Ação Emergencial da UC que definiu um buffer com raio de $3 \mathrm{~km}$. Dentro desse raio da ZA foi possível analisar por meio das imagens de satélite (Google Earth) pontos de alterações da vegetação no entorno da Flona, como o crescimento de assentamentos rurais, grandes empreendimentos consolidados e uma penitenciária.

Embora a Flona tenha um distanciamento em relação às cidades mais próximas, ela sofre uma grande ameaça das propriedades rurais que vem crescendo ao longo dos anos, essa expansão em direção à unidade são fatores de risco que merecem ser considerados. Os principais impactos previstos nessa situação são a supressão da vegetação natural e a intensificação do ruído e do tráfego de veículos de carga que trafegam a BR 343, como perturbadores da fauna. 
O plano de manejo estabelece o zoneamento e as normas que devem regular o uso da área e o manejo dos recursos naturais, bem como a implantação das estruturas físicas necessárias para a gestão da unidade. Considerando que o plano de manejo contempla a zona de amortecimento, o documento torna possível a tomada de decisões para melhorar a qualidade das unidades.

A ausência do plano de manejo para essas áreas é um dos fatores que contribui para o não cumprimento efetivo da preservação da biodiversidade da UC, sem regras claras que regulamentem o uso do solo, a gestão da unidade e o entendimento entre órgãos ambientais e a população no entorno são dificultados.

Segundo Diniz et al. (2018), a flexibilização da legislação quanto ao uso da terra nas ZA permitiu que a área desmatada e o número de desmatamentos localizados nesse raio de proteção aumentassem significativamente ano após ano. A expansão do desmatamento nas ZAs pode provocar danos irreparáveis sobre os ecossistemas, assim como os ecossistemas podem vir a gerar impacto sobre as populações que ali habitam.

Ainda assim, a legislação versa que, independentemente da existência de planos de manejo, deve ser estabelecida uma zona de amortecimento para as unidades de conservação com a intenção de minimizar impactos. O estabelecimento de uma zona de amortecimento para todas as unidades de conservação contribui com as restrições e reduz danos decorrentes do aumento das pressões sobre os espaços protegidos (RIBEIRO; FREITAS; COSTA, 2010).

\subsection{Grau de interação da Zona de Amortecimento e uso antrópico}

Embora a resolução Conama 428/10 defina um raio de no mínimo 2 km para unidades de conservação sem plano de manejo que é o caso da Flona de Palmares, a unidade sofre com a expansão do uso antrópico no seu entorno. O Plano de Ação Emergencial da Flona determina uma ZA com um raio de $3 \mathrm{~km}$, limites estes que não estão sendo respeitados, mesmo com essa determinação legal da resolução e o 
apontado no plano emergencial. Em decorrência disso foram observadas expressivas alterações na cobertura do solo em algumas áreas correspondentes à ZA da Flona, e principalmente nas áreas limítrofes à unidade.

De acordo com Sousa, Soares e Cerqueira Neto (2018), as pessoas que moram próximo à Flona de Palmares relatam não entender o que é uma unidade de conservação e muito menos uma Floresta Nacional, mas alguns reconhecem a importância da unidade para proteção da fauna, preservação da floresta, orientação ambiental e segurança da comunidade, e como um espaço de lazer. Na região da Flona de Palmares, a maioria das propriedades presentes usam atividades de desenvolvimento econômico de baixo impacto ambiental, como a agricultura de subsistência.

O Decreto de 21 de fevereiro de 2005 que Cria a Floresta Nacional de Palmares, no Município de Altos, Estado do Piauí, dispõe que as terras contidas nos limites da Floresta Nacional de Palmares que são elas a Penitenciária Major César, algumas propriedades privadas limítrofes com a UC, e a BR 343, pertencem ao patrimônio do Instituto Brasileiro do Meio Ambiente e dos Recursos Naturais Renováveis - IBAMA, averbadas sob o $n^{\circ}$ AV 2-2879, de 20 de outubro de 1994, do Livro n 3 -E, de Transcrições das Transmissões dos Imóveis, às fls. 128v./129, sob o n 2879, com data de 28 de maio de 1960, do Cartório do $1^{\circ}$ Ofício da Comarca de Altos, no Estado do Piauí.

A Zona de Amortecimento engloba áreas rurais densamente ocupadas e consolidadas, do qual os impactos são significativos, principalmente nas áreas limítrofes com a Flona. Dentro do raio de $3 \mathrm{~km}$ da ZA há empreendimentos como um parque de ecoturismo, um posto de gasolina, uma fábrica de ração, uma fábrica de alimentos e uma penitenciária (Figura 2), além destes, há também algumas propriedades privadas, assentamentos e comunidades, como as comunidades Vista Alegre e Mucuim, povoado Bom Gosto e o Assentamento da Reforma Agrária Federal Soturno-INCRA. Outro empreendimento observado na área da UC é a linha de transmissão de energia da Companhia Hidrelétrica do Vale do São FranciscoCHESF, que passa no interior da Flona. 
Figura 2 - Empreendimentos dentro da ZA da Flona de Palmares. (Fábrica de ração, fábrica de alimentos, posto de gasolina e a penitenciária Major César)
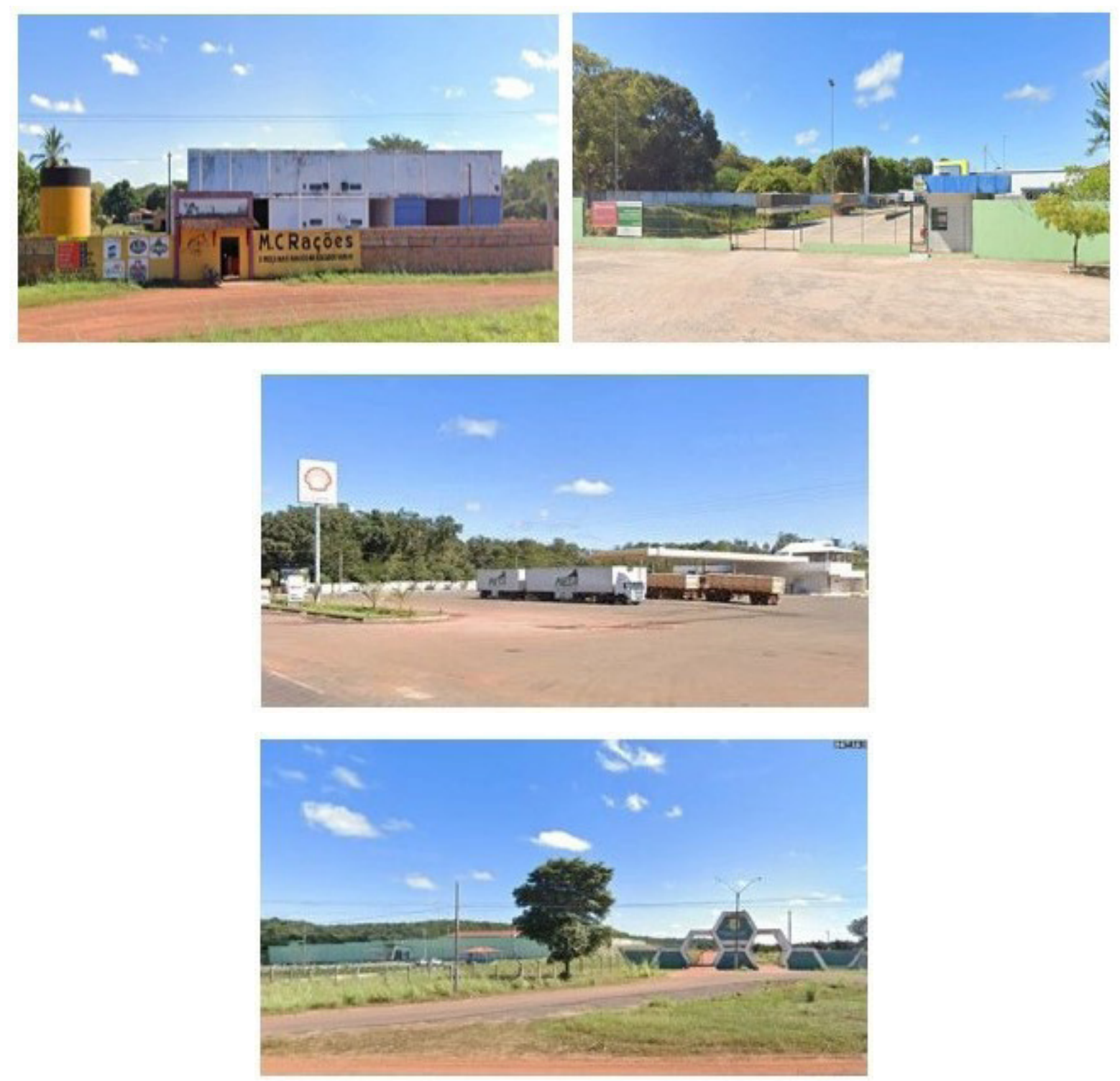

Fonte: Google Earth (2020). Organizado pelos autores (2020)

Feitosa (2014), em uma pesquisa realizada na Flona de Palmares sobre gestão participativa, realizou questionários com as comunidades no entorno da Flona e por meio de visitas realizadas na Comunidade Vista Alegre, verificou que a criação da UC proporcionou mudanças no comportamento dos moradores no entorno. Assim, segundo o autor, antes da criação da unidade os moradores praticavam a caça predatória de animais silvestres e os mantinham presos, praticavam queimadas e derrubavam árvores, muitas dessas madeiras de lei com alto grau de valoração. Com a UC, os moradores passaram a devolver os animais que apareciam em suas casas para a unidade. 
No entanto, devido à extensão da área florestal, muitos empreendimentos no entorno da Flona viram na região a oportunidade de usar essa área remanescente de vegetação para estimular o ecoturismo, o que permitiu o aumento de empregos e a distribuição de renda, pois não somente o ecoturismo foi instalado na área de abrangência da zona de amortecimento como também outros empreendimentos que viram na expansão da região uma oportunidade de negócio (SOUSA; SOARES; CERQUEIRA NETO 2018). A Figura 3 mostra o notável crescimento rural sobre a unidade.

Figura 3 - Expansão de assentamentos rurais sobre a Flona de Palmares no ano de 2019

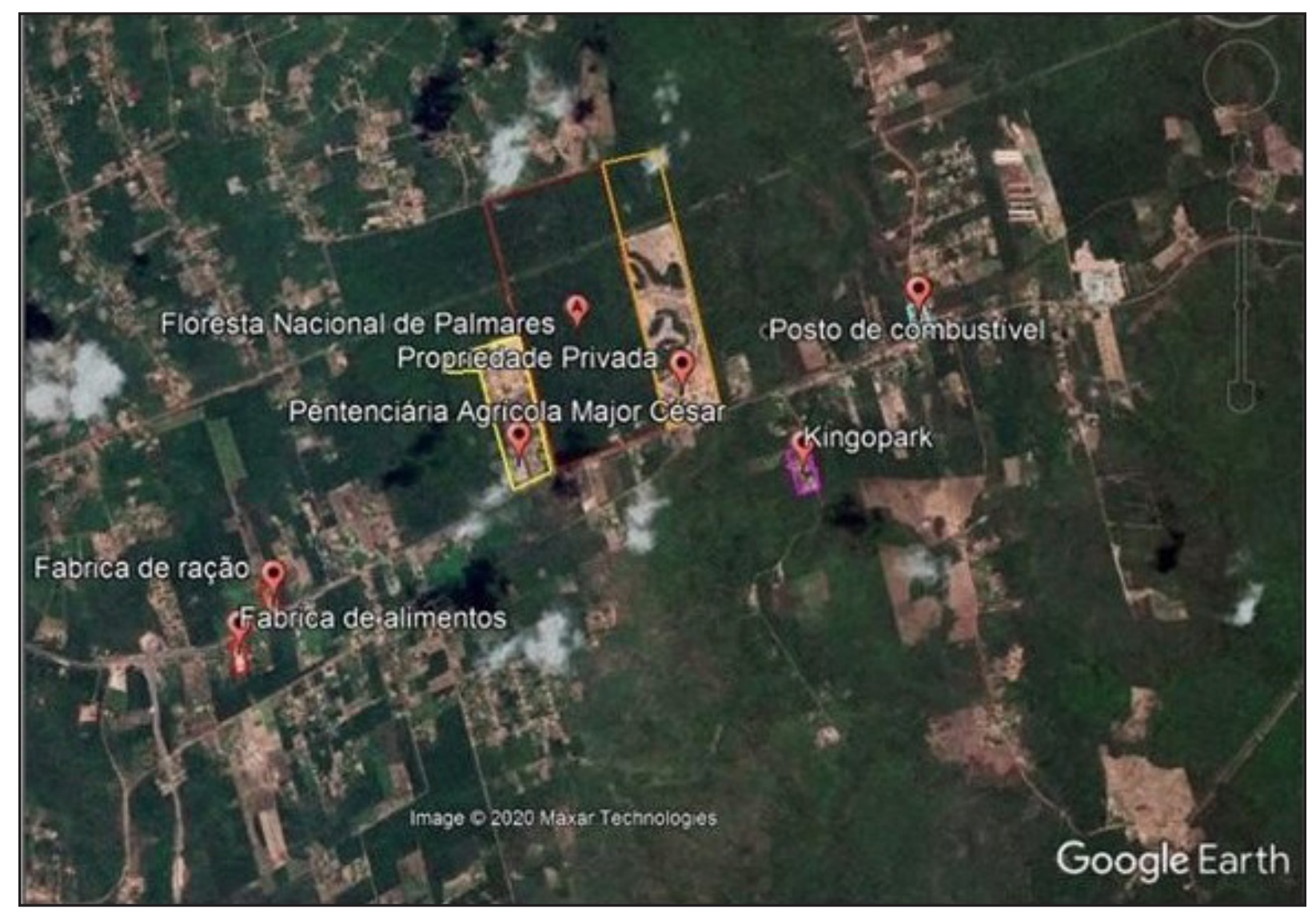

Fonte: Google Earth (2020). Organizado pelos autores (2020)

As imagens georreferenciadas e as do Google Earth foram de extrema importância para se compreender a dimensão espacial da ocupação humana na zona de amortecimento. A redução de área de cobertura vegetal é um sinal de pressão e 
alteração do uso do solo. Nesse sentido, os valores obtidos do NDVI foram entre 0,05 e 0,41 e podem ser observados na Figura 4.

Figura 4 - Mapa do NDVI da Zona de Amortecimento da Flona de Palmares

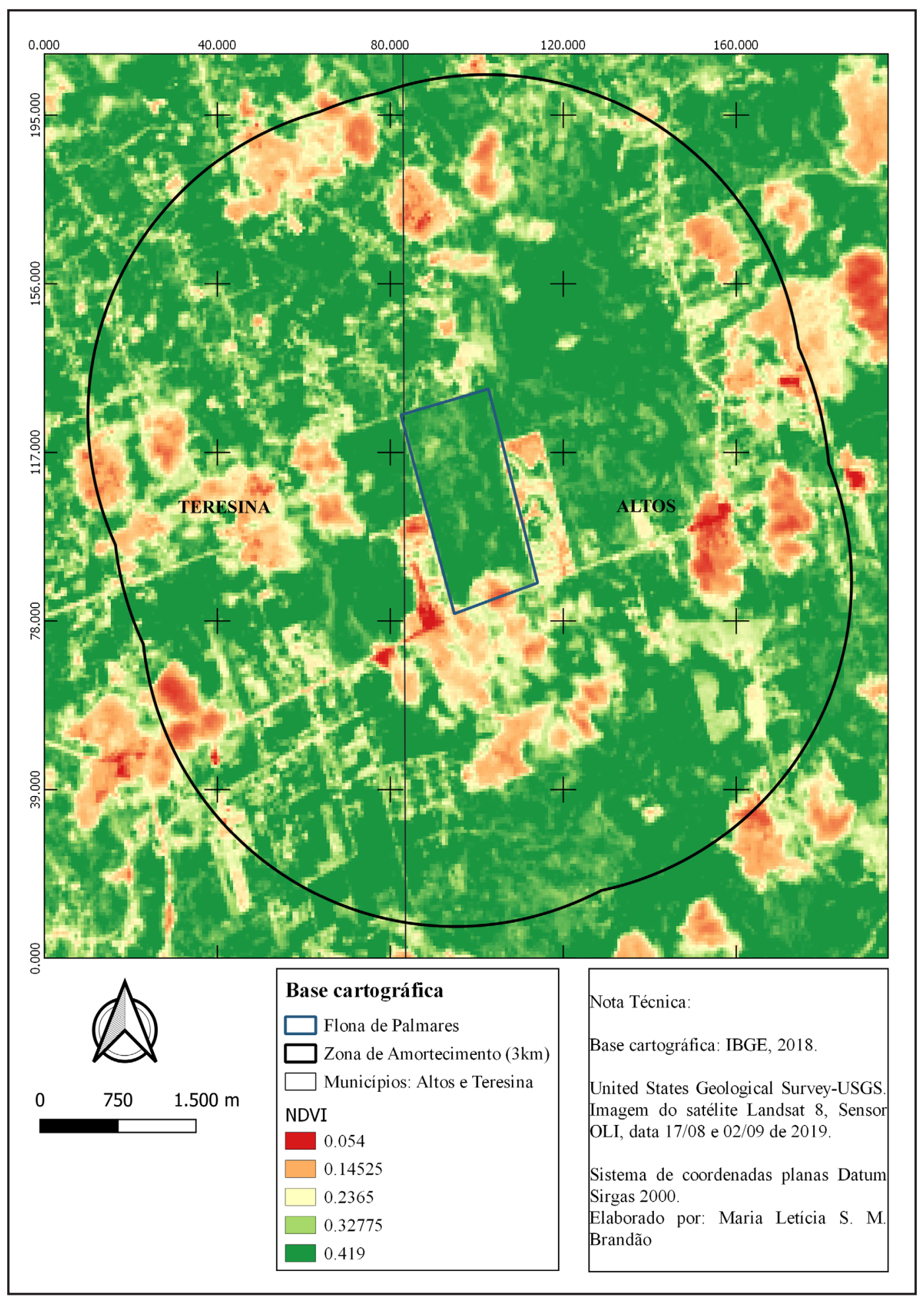

Fonte: Autores (2020) 
As áreas com coloração variando entre os tons de verde claro e escuro são indicativos de áreas vegetativas, os alvos de superfície representados pelas cores laranja e vermelho são indicativos de ausência de cobertura vegetal. Segundo Gameiro et al. (2016), o NDVI demonstra um alto desempenho na identificação e quantificação das classes de cobertura vegetal.

Azona de amortecimento da Flona de Palmares, pelo observado na representação acima, possui fragmentos de vegetação, todavia, as áreas com solo exposto merecem atenção visto que essas áreas cresceram significativamente ao longo dos anos e, como já mencionado, comprometem a qualidade ambiental e a função da UC.

O monitoramento por imagens permite a comparação entre tempos distintos de indicadores de qualidade ambiental, como a vegetação, para o enriquecimento do conhecimento da sua dinâmica ao longo do tempo. Avaliar a densidade da cobertura vegetal constitui-se como uma estrutura essencial para estudos voltados para análise ambiental, gestão e planejamento de recursos naturais, possibilitando o reconhecimento das áreas que estão sujeitas a variação da vegetação, essa compreensão facilita a realização do ordenamento territorial, de modo a atender as necessidades de conservação ambiental e as finalidades socioeconômicas (GAMEIRO et al., 2016; ALVES; LOVERDE-OLIVEIRA, 2020).

A proximidade da penitenciária Agrícola Major César e de outros empreendimentos limítrofes com a unidade podem contribuir para o surgimento de perturbações ambientais (Figura 5). Além de cercar todos os lados da Flona impedindo a existência de um corredor ecológico e limitando ainda a locomoção da Fauna da unidade, outro problema é o descarte incorreto de resíduos sólidos gerados pela penitenciária e por residentes próximos à UC nas áreas e estradas limítrofes com a unidade. A BR 343 é responsável pela perda constante de animais por atropelamento, bem como a intensificação do ruído, como perturbadores da fauna. 
Figura 5 - Mapa dos empreendimentos limítrofes a UC e o uso da ZA da Flona de Palmares no ano de 2017

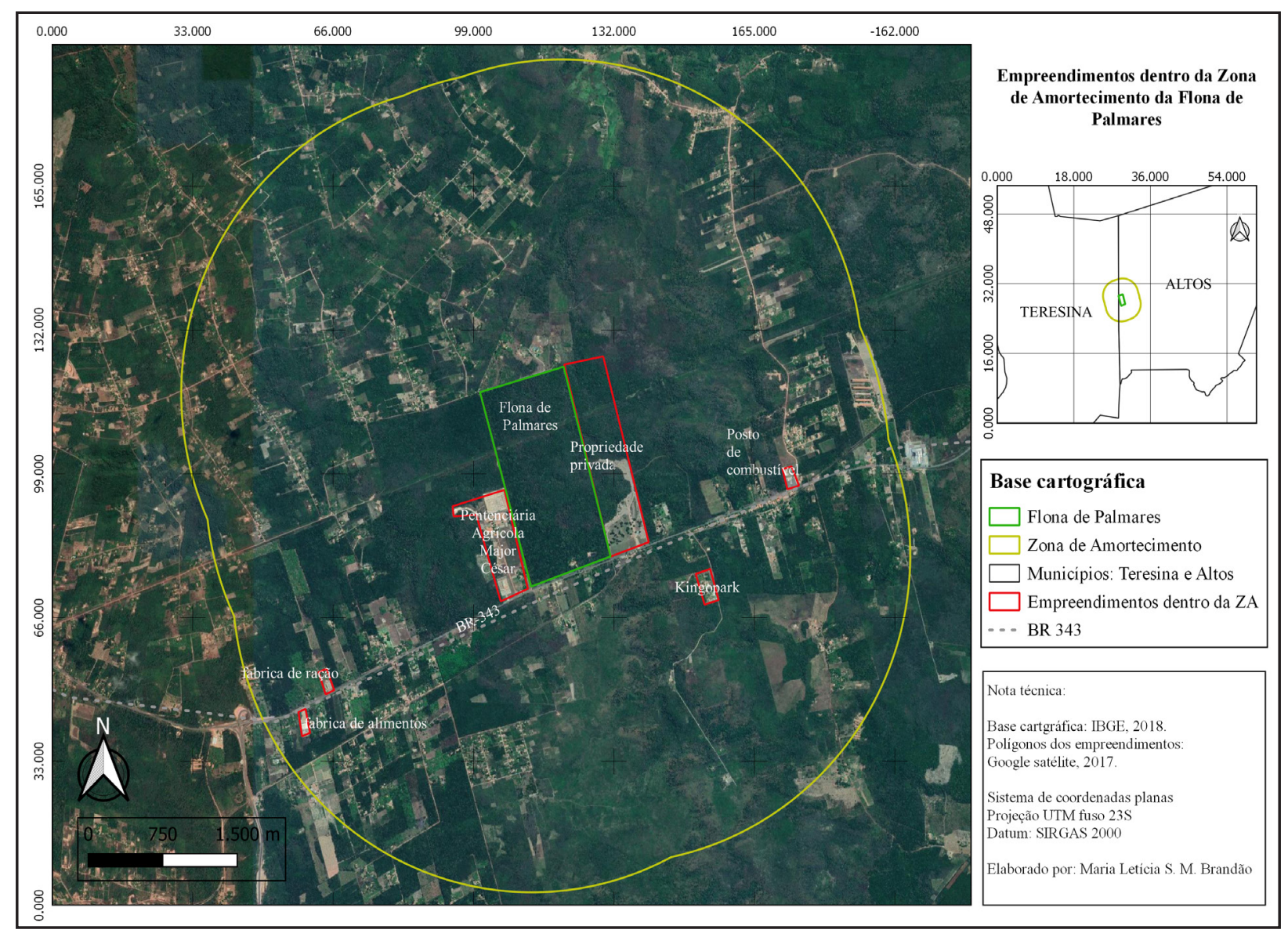

Fonte: Autores (2020)

Segundo Marques, Costa e Moura (2019), empreendimentos dentro da ZA de unidades de conservação são representações das distinções territoriais quanto aos tipos de usos da terra que estão ligados aos tipos de manejo e valores de investimentos empregados. São territórios onde relações desastrosas que envolvem o homem e a natureza se imbricam em diferentes espaços e, nessa situação específica, comprometem a UC.

Duas questões importantes são levantadas: a primeira é que há uma série de não conformidades frente à legislação vigente, visto que a Flona não tem plano de manejo instituído, o que dificulta as atividades de gestão e manutenção da proteção ambiental. Ressalta-se que mesmo partindo de um plano de caráter emergencial e 
dispositivo infralegal, com a Resolução Conama n 428/2010, tornando obrigatório o estabelecimento de um raio de $3 \mathrm{~km}$ de ZA, esta é parcialmente atendida. O outro aspecto diz respeito à intensa ocupação da área de ZA, fortemente influenciada pela primeira questão levantada e ausência de planejamento ambiental e controle e fiscalização dos processos.

Com esses resultados foi possível observar o avanço de propriedades rurais na ZA da Flona de Palmares, como também a remoção da vegetação que abrange consequentemente a Zona de Amortecimento da Flona. Observou-se também a inconformidade com a legislação vigente, a qual determina a sua preservação.

Todavia, segundo Sousa, Soares e Cerqueira Neto (2018), a pesquisa é incentivada na Flona de Palmares, a unidade possui trabalhos desenvolvidos dentro dos limites da área e destinados a sensibilização da comunidade local sobre a conservação do meio ambiente visando assim à redução e extinção da caça, redução da supressão vegetal na zona de amortecimento e extinção da supressão dentro da UC.

Tendo em vista que populações tradicionais e rurais são amplas no entorno de UC, para que haja eficácia das zonas de amortecimento é necessário o estudo e diálogo com esses grupos, atualmente o instrumento utilizado pela ciência é a percepção ambiental (GODOY; SOUZA, 2018).

\section{CONCLUSÕES}

Com base nos resultados desta pesquisa, observou-se que o ato de constituição da Zona de Amortecimento da Flona de Palmares, como instrumento legal de proteção, não tem sido suficiente para garantir efetivamente a proteção e redução do processo de intervenção antrópica na área.

Assim, os conflitos com os empreendimentos limítrofes com a unidade, e a carência de um plano de manejo eficiente e de sua aplicação, são alguns dos problemas identificados e que dificultam a efetividade da ZA da Flona de Palmares. 
A análise do índice de vegetação NDVI permitiu a observação de manchas significativas de redução na cobertura vegetal, sendo recomendada uma efetivação do cumprimento de proteção desse buffer.

As observações feitas permitem o reforço e a urgência da elaboração de um plano de manejo adequado à gestão da UC e do estabelecimento de um canal de diálogo amplo e continuado com as populações limítrofes à unidade, assim como com aquelas inseridas na ZA. Contudo a presente pesquisa pode contribuir não só com o reconhecimento da falta de fiscalização dos territórios legalmente protegidos e o cumprimento das suas respectivas legislações, como também pode servir de apoio para a execução de ações e políticas de preservação, não só para área de estudo, mas para outras Unidades na mesma situação.

\section{REFERÊNCIAS}

ALVES, G. B. M.; LOVERDE-OLIVEIRA, S. M. Uso do Índice de Vegetação por Diferença Normalizada (NDVI) para Análise da Distribuição e Vigor da Vegetação no Pantanal Norte. Revista Geografia, Londrina, v. 29, n. 1, p. 175-190, jan. 2020.

ANDRADE, Á. S. et al. Fragmentação da vegetação da bacia hidrográfica do Rio Marapanim, nordeste do Pará. Ciência Florestal, Santa Maria, v. 30, n. 2, p. 406-420, abr./jun. 2020.

BRASIL. Lei n 9.985, de 18 de julho de 2000. Regulamenta o art. 225, § 1으, incisos I, II, III e VII da Constituição Federal, institui o Sistema Nacional de Unidades de Conservação da Natureza e dá outras providências - SNUC. Diário Oficial da União, Brasília, DF, 19 jul. 2000. Disponível em: http://www.planalto.gov.br/ccivil_03/leis/l9985.htm. Acesso: 09 jan. 2020.

BRASILEIRO, D. P. et al. Importância do estabelecimento da zona de amortecimento: um estudo de caso do Parque Nacional de Sete Cidades, Estado do Piauí, Brasil. Revista Brasileira de Gestão Ambiental e Sustentabilidade, João Pessoa, v. 5, n. 10, p. 789-798, ago. 2018.

CASTRO, P. F. Zona de amortecimento do parque nacional da tijuca, conflitos e ausência de planejamento integrado. 2018. Monografia (Especialização em Gestão Pública) - Escola Nacional de Administração Pública, Brasília, 2018.

CONSELHO NACIONAL DO MEIO AMBIENTE (Brasil). Resolução n 428, de 17/12/2010. Dispõe, no âmbito do licenciamento ambiental sobre a autorização do órgão responsável pela administração da Unidade de Conservação (UC). Diário Oficial da União, Brasília, DF, 20 dez, 2010. Disponível em: http://www2.mma.gov.br/port/conama/legiabre.cfm?codlegi=641. Acesso: 09 jan. 2020. 
DINIZ, J. M. F. S. et al. Detecção de desmatamentos em Zonas de Amortecimento: um estudo de caso nas Unidades de Conservação das Bacias do Rio Pardo e Jequitinhonha, Minas Gerais. Advances in Forestry Science, Cuiabá, v. 5, n. 3, p. 417-423, 2018.

FEITOSA, A. A. Gestão participativa em unidades de conservação: um estudo de caso na floresta nacional de palmares em Altos/PI. In: CONGRESSO BRASILEIRO DE GESTÃO AMBIENTAL, 5., Belo Horizonte, 2014. Anais [...]. [S. I.: s. n.], 2014.

FERREIRA, M. R. V. et al. Detecção de Construções em Imagens RapidEye com Uso do Operador Brec Urban Focus: estudo aplicado a zona de amortecimento da ESECAE DF. Revista Brasileira de Geografia Física, Pernambuco, v. 12, n. 3, p. 1074-1092, 2019.

GALVÃO, J. R. Percepção dos moradores da zona de amortecimento acerca de sua relação com a floresta nacional de passo fundo, Brasil. 2018. Dissertação (Mestrado em Ciências Ambientais) - Universidade de Passo Fundo, Passo Fundo, 2018.

GAMEIRO, S. et al. Avaliação da cobertura vegetal por meio de índices de vegetação (NDVI, SAVI e IAF) na Sub-Bacia Hidrográfica do Baixo Jaguaribe, CE. Revista Terræ, Campinas, v. 13, p. 15-22, 2016.

GODOY, G. A.; SOUZA, A. D. G. Percepção ambiental de moradores da zona de amortecimento do parque municipal da serra de são domingos - poços de caldas (MG). Revista Boletim de Geografia, Maringá, v. 36, n. 3, p. 144-159, nov. 2018.

$\mathrm{KOCH}, \mathrm{A}$. H. S. Zona de amortecimento da floresta nacional de são Francisco de Paula: alterações da cobertura do solo. Revista Metropolitana de Sustentabilidade, São Paulo, v. 6, n. 3, p. 123-139, set./dez. 2016.

LEITE, A. P.; SANTOS, G. R.; SANTOS, J. E. O. Análise temporal dos índices de vegetação NDVI e SAVI na estação experimental de Itatinga utilizando imagens Landsat 8. Revista Brasileira de Energias Renováveis, Curitiba, v. 6, n. 4, p. 606-623, 2017.

LOPES. J. C. R. Floresta nacional: implantação, gestão e estudo de caso - flona de palmares. 2007. Dissertação (Mestrado em Desenvolvimento e Meio Ambiente) - Universidade federal do Piauí, Teresina, 2007.

MARQUES, A. L.; COSTA, C. R. G.; MOURA, D. C. Parque estadual mata do pau ferro (areiaparaíba): zona de amortecimento e espaços de conflitos. Revista Geoambiente, Jataí, n. 34, p. 1-18, 2019.

MOREIRA, V. S. Zonas de amortecimento em unidades de conservação: normas, estudos de caso e recomendações. 2015. Dissertação (Mestrado em Gestão de Áreas Protegidas da Amazônia) - Instituto Nacional de Pesquisas da Amazônia, Manaus, 2015.

POLONIO, V. D. Índices de vegetação na mensuração do estoque de carbono em área com cana-de-açúcar. 2015. Dissertação (Mestrado em Agronomia) - Universidade Estadual paulista, Faculdade de Ciências Agronômicas de Botucatu, Botucatu, 2015. 
PROST, C.; SANTOS, M. A. Gestão territorial em Unidades de Conservação de Uso Sustentável e incoerências no SNUC. Revista Novos Cadernos NAEA, Belém, v. 19, n. 1, p. 143-158, jan./ abr. 2016.

PIGNATON, R. R.; SILVA, M. A.; SILVA, J. R. Caracterização de áreas da zona de amortecimento do parque estadual do rio doce com a utilização de imagens do satélite landsat 8 e do programa erdas. Revista Anais SNCMA, Anápolis, v. 8, n. 1, p. 1-10, out. 2017.

REIS, T. E.; COSTA, V. C. Análise da vulnerabilidade na zona de amortecimento do Parque Estadual do Ibitipoca (MG), com o uso de SIG. Revista Geosul, Florianópolis, v. 32, n. 63, p. 77-96, jan./abr. 2017.

RIBEIRO, M. F.; FREITAS, M. A. V.; COSTA, V C. O desafio da gestão ambiental de zonas de amortecimento de unidades de conservação. In: SEMINÁRIO LATINO-AMERICANO DE GEOGRAFIA FÍSICA, 6., 2010. Anais [...]. [S. I.: s. n.], 2010. p. 1-11.

ROUSE, J. W. et al. Monitoring vegetation systems in thegreat plain with ERTS. In: EARTH RESOURCES TECHNOLOGY SATELLITE - SYMPOSIUM, 3., 1973. Proceedings [...] Washington: [s. n.], 1973. v. 1. p. 309-317.

SOUSA, G. A.; SOARES, L. H. C.; CERQUEIRA NETO, C. F. Plano de ação emergencial floresta nacional dos palmares. Altos: Governo do Estado do Piauí, 2018.

SOUZA, H. T. R. Zoneamento Geoambiental da Unidade de Conservação Refúgio de Vida Silvestre Mata do Junco (Capela SE). 2011. Dissertação (Mestrado em Desenvolvimento e Meio Ambiente) - Universidade Federal de Sergipe, São Cristóvão, 2011.

TAMBOSI, L. R. Análise da paisagem no entorno de três unidades de conservação: subsídios para a criação da zona de amortecimento. 2008. Dissertação (Mestrado em Ecologia) - Universidade de São Paulo, São Paulo, 2008.

WINAGRASKI, E. et al. Forest Fragmentation on the National Forest of Irati Bufferzone - Brazil. Revista Ciência e Natura, Santa Maria, v. 40, e14, dez. 2017.

\section{Contribuição de Autoria}

\section{1 - Maria Letícia Stefany Monteiro Brandão}

Gestora Ambiental, Pesquisadora

https://orcid.org/0000-0001-6488-1300•marialeticia.gab@gmail.com

Contribuição: Escrita - primeira edição, Metodologia, Validação 


\section{2 - Francisco das Chagas Paiva Silva}

Gestor Ambiental, Aluno de especialização em Geoprocessamento https://orcid.org/0000-0003-2041-3331•franciscopaiva745@gmail.com

Contribuição: Software

\section{3 - Ana Carolina Chaves Fortes}

Gestora Ambiental, Ma., Professora

https://orcid.org/0000-0003-3044-0229•carolina.chaves@ifpi.edu.br

Contribuição: Escrita - revisão e edição

\section{4 - Gaspar da Silva Alencar}

Geógrafo, Chefe da Floresta Nacional de Palmares

https://orcid.org/0000-0002-2764-1516•gaspargeografo343@gmail.com

Contribuição: Supervisão

\section{5 - Israel Lobato Rocha}

Gestor Ambiental, Me., Professor

https://orcid.org/0000-0002-4496-9935 • israel.lobato@ifpi.edu.br

Contribuição: Metodologia

\section{6 - Bruna de Freitas Iwata}

Gestora Ambiental, Dra., Professora

https://orcid.org/0000-0002-6465-9731•iwata@ifpi.edu.br

Contribuição: Escrita - revisão e edição, Administração do projeto, Conceituação, Obtenção de financiamento

\section{Como citar este artigo}

Brandão, M. L. S. M.; Silva, F. C. P.; Fortes, A. C. C.; Alencar, G. S.; Rocha, I. L.; Iwata, B. F. O papel das zonas de amortecimento na efetividade da proteção ambiental da Floresta Nacional de Palmares, Piauí, Brasil. Ciência Florestal, Santa Maria, v. 31, n. 4, p. 1789-1811, 2021. DOI 10.5902/1980509848035. Disponível em: https://doi.org/10.5902/1980509848035. 